\title{
Colonialism on display: Indigenous people and artefacts at an Australian agricultural show
}

\author{
Joanne Scott and Ross Laurie
}

\begin{abstract}
There was a continual swarm of interested visitors to the aboriginal court, which certainly formed one of the most interesting features of the exhibits within the pavilion. $M$ any and genuine were the expressions of surprise and appreciation of the quality and range of the work.
\end{abstract}

Week, 22 A ugust 1913

Recent scholarship, both within Australia and internationally, has explored the representation of Indigenous peoples through the international expositions and travelling circuses of the 19th and early 20th centuries. Those events highlighted the artefacts of subordinated cultures and showcased the 'exotic', revealing a transnational fascination with displaying Indigenous people and their material culture. ${ }^{1}$ Curiously and by contrast, a more localised site for such representations in A ustralia, the annual agricultural show, has rarely attracted the attention of historians of race relations. ${ }^{2}$ Yet as a key site for white settler society, with its celebration of economic and cultural advances and its commitment to the ideology of progress, the annual show repays closer investigation. In contrast to the international events at which nations and colonies sought to show off their wares to their global competitors and markets, the agricultural shows in Australia primarily targeted local audiences. They offer insights into the values of white settler communities, and provide opportunities to reflect on local knowledge of and aware ness of Aborigines. They also prompt, although do not necessarily answer, questions about the Indigenous people who created items for and appeared as exhibits at annual agricultural shows. Whereas historians have identified an emphasis at international expositions on a narrative of progress in which indigenous peoples represented the 'primitive' and Western cultures the 'advanced', the organisers of A boriginal displays at local shows were more likely to offer a story of Indigenous people's progress from a state of 'barbarism' to economic usefulness. ${ }^{3}$ Like their international counterparts,

1. For example, Bank 2002; McKay 2004; Poignant 2004. Earlier studies include Greenhalgh 1988 and Rydell 1984 and 1993.

2. The main exception is Broome 1996 and 1998, whose studies of sideshow alley and tent boxing shows in Australia examine the experiences of A boriginal boxers. 
however, local shows also relied on the appeal of the 'exotic' in their presentation of Indigenous peoples and artefacts to a non-Indigenous audience.

This article offers a case study of the Brisbane Exhibition from its inception in 1876 through to the 1910s when its Aboriginal courts ${ }^{4}$ were among the event's major attractions. One of the largest agricultural shows in Australia and one of the oldest annual events in post-contact Queensland, the Brisbane show has been a central feature of the community's social life and has consistently attracted huge crowds. The choice of time period, which spans the late frontier and the early post-frontier eras, emphasises the importance of identifying absences as well as inclusions in tracing a history of Indigenous participation in and representation at agricultural shows. It facilitates an assessment of the significance of Aboriginal displays and performances to the Queensland government authorities who organised them and the predominantly white audiences who flocked to the exhibits. In the 1910s, Brisbane's annual show was the most important medium through which those authorities sought to convey to the general public a vision of Indigenous people as a compliant group who could be trained to be useful workers, were subject to segregative practices, but were reassuringly inculcated with aspects of the broader community's value system. Accounts of visitors' reactions to the A boriginal exhibits suggest, however, that they may have been more interested in those items deemed 'exotic' and 'authentically Aboriginal' than those objects which represented the achievements of the reserve and mission system. How the Indigenous creators and participants who provided the content of the displays viewed their role at the Exhibition remains frustratingly elusive.

\section{Initial appearances}

Exhibits of Aboriginal people and objects did not become a significant feature of the Brisbane Exhibition until the 1910s. Nonetheless, it is possible to trace an Aboriginal presence from the first show, held in 1876. Attracting more than 34,000 visitors, the inaugural Brisbane Exhibition celebrated Queensland's material and social progress as a young, self-governing colony within the British Empire. By then, race relations in south-east Queensland had entered into a post-frontier milieu. Frontier conflict would continue in the west and north of the colony, however, into the early years of the 20th century.

The 1876 Exhibition, with its focus on the achievements and aspirations of white colonial society, almost entirely ignored the existence of Indigenous people. From more than 1700 exhibits, there was just one display crafted by Indigenous Australians. Class 540 'Furniture, Upholstery' included an entry by the Governor of Sydney Gaol, JC Read, of 'Mats and matting made by aborigines in Darlinghurst Gaol'. The National Agricultural and Industrial Association of Queensland (NAIAQ), which hosted the show, awarded Read a first prize for his exhibit. ${ }^{5}$ A boriginal people also appeared as the subjects of white settler art. In 1876 the fine arts section included 'Guère pictures,

3. This distinction between international and local shows is not absolute, but our findings and those of Heaman 1999, who has explored local shows in Canada as well as Canadian participation in international expositions, suggest that it is a pattern.

4. 'Court' was the term given to a section of an exhibition.

5. Queenslander, 26 August 1876: 11. 
Australian bush characters and Aboriginals'. ${ }^{6} \mathrm{~A}$ showcase in the annexe which displayed items sent from $\mathrm{N}$ ew South Wales included 'an exceedingly handsome flower stand of oxydised silver representing a blackfellow sitting under a fern tree, with a dead kangaroo lying at his feet'. ${ }^{7}$ On their own, these items do not represent a sufficient basis for any conclusive analysis. It is tempting to emphasise the fact that neither the mats nor the flower stand originated in Queensland, instead deriving from a colony where frontier conflict had already subsided. Such an analysis, though, with its putative link between frontier violence and the lack of local A boriginal representation at a major public forum, disrupts a pattern based on other popular practices and events in Queensland.

In general, it was the absence rather than the presence of exhibits relating to Indigenous Australians that was noteworthy at Brisbane's annual agricultural shows of the 19th century. That absence is initially unexpected, given exhibitionary practices in the last decades of the 19th century. The frontiers of Queensland had become 'a hunting ground for collectors of exhibits for circuses, exhibitions and museums'. ${ }^{8}$ Queensland contributed photographs of and objects from A boriginal people to international expositions from as early as the 1870s. In 1880 Colonial Secretary AH Palmer loaned two mummified figures from Stephen Island in the Torres Strait to Queensland's court at the Sydney International Exhibition of 1879-1880 and the Melbourne International Exhibition of $1880-1881 .{ }^{9}$ Public displays of Indigenous people became a feature of entertainment in the colony from the 1890s, with Brisbane citizens attending the 'Wild Australia' Show, which included Aboriginal people performing corroborees and throwing boomerangs and spears. In 1897 locals visited the Queensland International Exhibition, held on the same site as the annual Brisbane show, and examined the native weapons stored in the Bush House. They could also observe the 'Thirty Chosen Warriors', Aboriginal men from, ironically, the newly established Fraser Island Reserve, an experiment in segregation. The Aboriginal participants demonstrated boomerang and spear throwing, performed corroborees, staged mock battles, and played football. ${ }^{10}$

Private collectors, entrepreneurs and government officials in Queensland thus participated in an international phenomenon that Penelope Edmonds has summarised as 'globalised, social-Darwinian and anthropological discourses on modernity, progress and empire, where "primitive" people on display came to represent traces of the early stages of a highly organised evolutionary sequence'. ${ }^{11}$ On occasion, individuals operated in all three capacities. Archibald Meston, for example, the colony's selfproclaimed Aboriginal 'expert', collected Aboriginal artefacts and people. As a commercial operator he toured his 'Wild Australia' shows, featuring those artefacts and individuals (with disastrous results for some of the performers), before acting as an adviser to the Queensland government on how to deal with the Aboriginal 'problem' in the mid-1890s. He was the architect of the $1897 \mathrm{~A}$ boriginals Protection and Restriction of

\footnotetext{
6. Queensland Intercolonial Exhibition 1876 Catal ogue, Class 524.

7. Queenslander, 2 September 1876: 11.

8. McKay 1998: 234.

9. M cKay 2004: 35. A third figure was sent to the Queensland court from the private collector, pastoral ist and banker, Ferdinand Sachs of Townsville.

10. Rutlidge 1897: 193; McKay 1998: 243.

11. Edmonds 2006: 135-136. See al so Poignant 2004.
} 
the Sale of 0 pium A ct and accepted the post of Queensland's Southern Protector of A borigines in 1898. In this latter position, Meston arranged for 25 Aboriginal Queenslanders to participate in the 1901 re-enactment of Captain Cook's landing at Botany Bay, as well as organising an 'Aboriginal arch' for the federation celebrations in Brisbane; the arch featured Indigenous men, women and children, with weapons and other artefacts, among grass-trees, staghorns and ferns. ${ }^{12}$

A midst this mixture of privately-organised and state-endorsed displays of Aboriginal people and artefacts, the near absence of A boriginal people at the local Brisbane Exhibition requires analysis. No direct evidence has been found, but the likeliest explanation derives from a combination of factors. The local show was primarily intended to promote and present the best outputs of Queensland's pastoral, mining, agricultural and secondary industries as well as showcasing new developments that could further advance the colony. It also provided opportunities to reflect on and judge social and cultural progress, with sections devoted to schoolwork, fine arts and domestic crafts. It seems doubtful that the organisers of the 19th-century Brisbane Exhibitions would ever have conceived of a role for A boriginal Queenslanders within such a framework. Kay Anderson has noted that 'the genre of the agricultural show enacts in thoroughly ritualistic fashion a triumphal narrative of human ingenuity over the nonhuman world' ${ }^{13} \mathrm{In}$ Queensland, such human ingenuity was presumed to be the domain of the colonists, not the colonised. In addition, the annual Brisbane show targeted a local audience that, in the 19th century, could be assumed to have some degree of familiarity with the presence of Aboriginal people, in contrast to the overseas expositions at which images and artefacts of Australian Indigenous people could be presented as items of curiosity. A complaint from Meston to the colony's H ome Secretary on the occasion of the Queensland International Exhibition in 1897 also suggests a degree of repugnance by local citizens to visible evidence of Aboriginal people in the city. According to Meston, 'it seems specially undesirable for aboriginals - men and women - to be rambling about Brisbane in the vicinity of the Exhibition in a more or less demoralised condition while the metropolis is full of visitors'. ${ }^{14}$

The ongoing violence between Indigenous and non-Indigenous people on Queensland's frontiers as well as the idea of Queensland as an uneasy or nervous outpost of Empire also contribute to an explanation for the near complete absence of A boriginal people from the local show. In his path-breaking study of race relations in colonial Queensland, Raymond Evans declared that 'the initial settlement of almost every district in Queensland was accompanied by a period of violence, sometimes short and decisive, sometimes extending over many years, but always more or less severe'. ${ }^{15}$ By the 1870s the frontier had contracted to the northern and western parts of Queensland. In 1876, the year of Brisbane's inaugural show, politician John Macrossan declared in the colony's Legislative Assembly that 'the system of continual war ... was being carried on at the present time to utter extermination'. ${ }^{16}$ The particular discourse

\footnotetext{
12. Evans 2001: 76-77.

13. Anderson 2003: 423 .

14. Cited in Blake 1987: 50.

15. Evans et al 1993: 38.

16. Evans et al 1993: 53.
} 
of civilisation, settlement and improvement which dominated the formal elements of agricultural shows could not accommodate 'unsettled' narratives of frontier conflict, dispossession and destruction. The unease associated with white colonists' occupation of the land was well outside the frameworks of the Brisbane Exhibition, as represented in the show's carefully constructed schedules, catal ogues and displays.

While there seemed to be no place for an Aboriginal presence in the formal, regulated sections of the Brisbane Exhibition, except in colonists' artistic depictions, the unruly space that would become sideshow alley eventually included Aboriginal people, most obviously in the boxing tents. We have been unable, however, to discern any comparable Aboriginal presence in the 19th century. Presumably, the local entrepreneurs such as Meston who sought commercial success through the display of A boriginal people on the international circus and exhibition circuits did not regard the local show as financially attractive. As noted above, it is unlikely that the NAIAQ ever contemplated the need for Aboriginal exhibits but in any case the organising committee tended to rely on exhibitors to generate the content of the show, rather than initiating or actively seeking specific exhibits. ${ }^{17}$

\section{Aboriginal courts in the 1910 s}

The deliberate, state-endorsed and organised display of Indigenous people and their products at the Brisbane Exhibition did not begin until 1909. By then, the impact of the A boriginals Protection and Restriction of the Sale of O pium A ct of 1897, legislation which came to control almost every aspect of the lives of those Aboriginal people who fell under its aegis, was well established. The frontier era was over and the removal of A boriginal peopleto reserves and missions, which had begun in Queensland in the late 19th century, was part of the pattern of post-frontier race relations. Comparatively few white citizens in Brisbane were in direct contact with A boriginal people. In his annual report for 1910, the Chief Protector of A boriginals referred to 'the new regulations prohibiting any further engagement of girls within [Brisbane] city boundaries ... being steadily and firmly carried out'. ${ }^{18}$ According to the Chief Protector, there were just 38 Aboriginal girls and women in domestic service in Brisbane in $1911 .{ }^{19}$

Across the decade of the 1910s, the displays of A boriginal people and goods at the Brisbane Exhibition were the primary source of information for most local citizens about Indigenous Queenslanders. The only other site in the city which offered regular access to aspects of A boriginal society was the Queensland Museum; its annual attendance figures were approximately one-half of the attendance figures for each Exhibition. The Museum's holdings of objects relating to A boriginal A ustralia, however, were significantly larger, increasing from some 3000 items to almost 6000 items between 1910 and 1917, with a small number of the acquisitions sourced from the Brisbane Exhibition. During the 1910s, the Museum also initiated a popular science lecture series which included presentations on A boriginal Australia. ${ }^{20}$ With the exception of reports on the

17. There were, of course, exceptions to this tendency and the NAIAQ certainly influenced potential exhibitors through its choice of competition categories, prizes, and rules and regulations.

18. A nnual Report of the Chief Protector of A boriginals for the year 1910, Queensland Parliamentary Papers (hereafter QPP) 1911-12, 3: 11.

19. Blake 1987: 56. 
displays at the Brisbane Exhibition, local newspapers rarely featured stories about A boriginal people in this era. The one account of Aboriginal culture available to a substantial audience was an article in the Q ueensland School Reader for Grade 5 children, first issued in 1913 and widely available from 1915. This short article, 'A boriginal rock pictures', informed children that 'on the walls of caves and on the smooth surfaces of rocks in various parts of Australia are found rude pictures, drawn doubtless by the aboriginal inhabitants. Rough though the work may be, it shows that the "blackfellows" were not altogether without appreciation of the beauties of art..21 During the 1910s, for most inhabitants of Brisbane and the surrounding districts, the annual show was probably their most memorable interaction with Indigenous people. The Aboriginal courts, which became one of the most popular features of the Brisbane Exhibition, presented a reassuringly anodyne and highly censored view of Queensland race relations and the institutionalisation of Indigenous people, enlivened by references to a 'colourful' past. The stunning contrast between the benign images offered for public consumption at the annual show during this decade and the contemporary realities of forced removals; the establishment of punishment centres such as Palm Island; shocking mortality rates on reserves and missions whose inhabitants were ravaged by epidemics; substandard educational, health and welfare provisions; and the extent of official surveillance and control over Indigenous people is breathtaking in its audacity.

From 1909, Aboriginal people became substantially more visible at the Brisbane Exhibition when Bertram Lipscombe, the Superintendent at Barambah A boriginal Settlement, near Murgon in south-east Queensland, sent a non-competitive display to the show 'in order to exhibit and encourage the work of the children'. 22 The display included sewing samplers, garments and copybooks, mimicking the categories in the schoolwork section of the Exhibition which catered for (non-Indigenous) children enrolled in public, private and Catholic schools. Writing half a century after the event, JW Bleakley, amateur ethnographer and the Chief Protector of A boriginals from 1914 to 1942, claimed that the impetus for the initial display came from Aboriginal children who, 'having seen the white schools exhibit at the Brisbane Exhibition, expressed a desire to exhibit some of their own work'. ${ }^{23}$ This claim raises questions about whether and how often reserves and missions in south-east Queensland organised trips to the Exhibition, questions that surviving records at Queensland State Archives do not appear to answer. A gain according to Bleakley, the first display in 1909 was classed as 'non-competitive' because of the assumption by government officials that Indigenous exhibitors would suffer a 'handicap' if they competed openly with white exhibitors. ${ }^{24}$ Barambah's Superintendent expressed disappointment that, although the show's organisers had promised 'special awards where merit justified it', no prizes were distributed despite the fact that 'many people capable of judging considered they were quite equal to many of the other successful exhibits'. ${ }^{25}$ The following year, the

20. Mather 1986: 206-11.

21. Queensland School Readers, Book V, Brisbane, Department of the Public Instruction, 1913: 142. According to educational historian Greg Logan, the Readers 'remained basically the same until they were phased out in the 1970s' (Logan 1989: 7).

22. A nnual Report of the Chief Protector of A boriginals for the year 1909, QPP 1910, 3: 21.

23.

Bleakley 1961: 190. 
Superintendent was able to announce that the children had secured prizes for their work at both the Brisbane and Gympie shows and in 1911 children's work from Barambah was on display at the Brisbane, Brookfield, Wondai and other local shows. Other reserves and missions also began to prepare items for display at the Brisbane Exhibition.

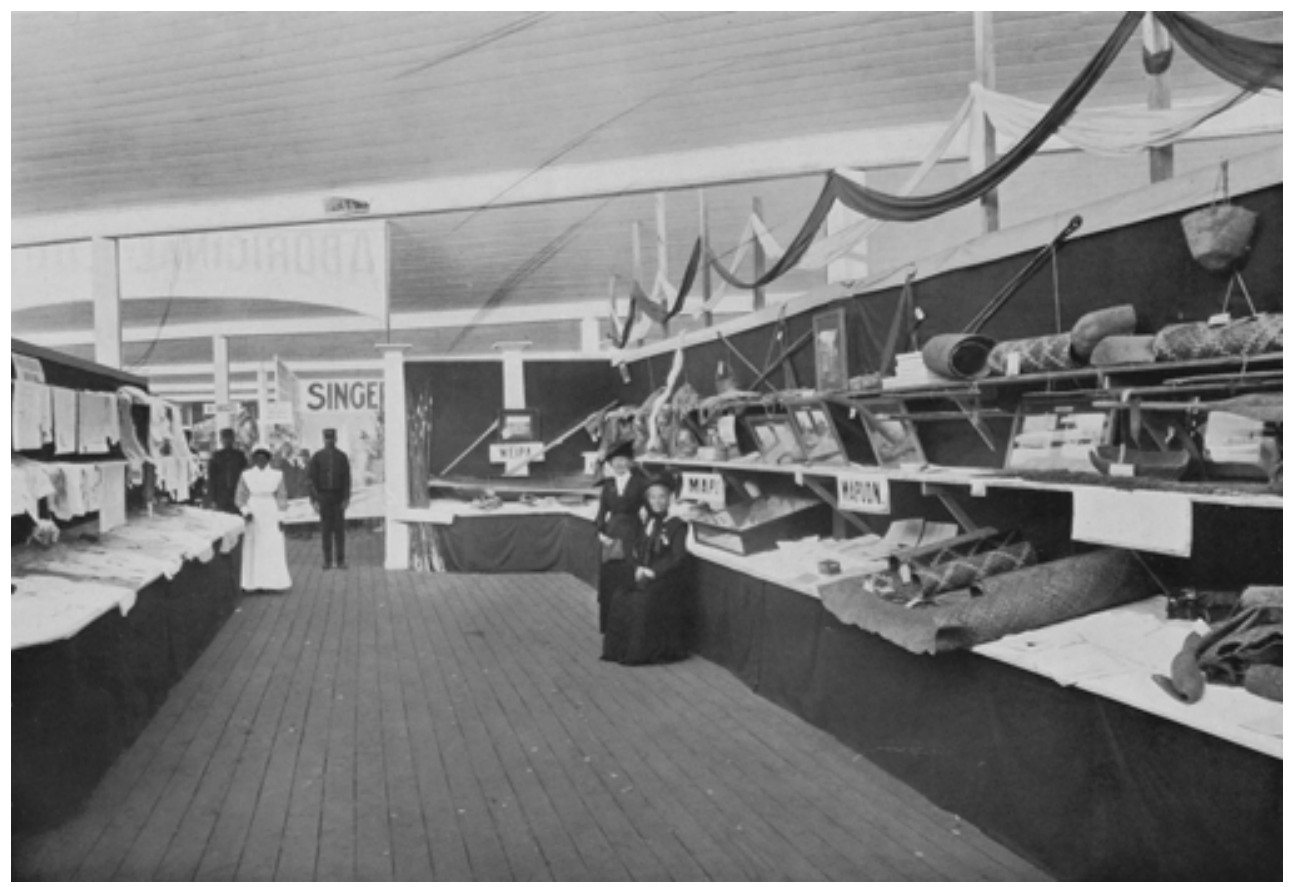

Fig 1. 'Aboriginal court', Brisbane Exhibition, 1914, from the Annual Report of the Chief Protector of Aboriginals for the year 1914, Queensland Parliamentary Papers 3, 1915-16.

The 'Coronation Show' of 1911 included the first major 'A boriginal court' at the metropolitan exhibition. The Q ueenslander recorded that the display of work by Aborigines and Torres Strait Islanders from government reserves and church missions was 'one of the most popular features' of the Exhibition. ${ }^{26}$ Conducted under the auspices of Bleakley, then Deputy Chief Protector of Aborigines, the court's primary purpose was to advertise the efforts of the government and missions to, supposedly, uplift Indigenous Queenslanders, an orientation made clear in departmental memoranda. Bleakley wrote to the Superintendents of Missions that 'exhibits of work of all descriptions done by natives old or young is desired and especially such as may illustrate the development of the institution and the education of the natives'. ${ }^{27}$ Contemporary newspaper stories similarly highlighted the role of reserve and mission training: 'On the whole the aboriginal

25. A nnual Report of the Chief Protector of A boriginals for the year 1909, QPP 1910, 3: 21-22.

Certificates of merit were awarded in later years.

26. Q ueenslander, 19 A ugust 1911: 39.

27. Memorandum from Deputy Chief Protector of A boriginals, 1 July 1911, Queensland State Archives (QSA) A/ 58808. 
exhibit was a proof of the good work now being done amongst the descendants of the original possessors of this fair land, and of their dexterity and appreciation of detail. ${ }^{28}$ As an exercise in public relations, the court also signalled the state's success in distancing itself from earlier controversies and failures relating to the reserve and mission system.

The list of exhibits from the Salvation A rmy-run Deebing Creek Aboriginal Home, near Ipswich in south-east Queensland, reflected a theme of evolution from the primitive and picturesque to the tame and pragmatic with display items ranging from 'one shield and four nullas' to examples of practical sewing and fine needlework. With the exception of the shield and nulla, an axe, and perhaps the amal gam of old and new contained in a 'silk thread dilly bag', the more than 40 items sent from the Home were the result of training imparted at the mission to its inmates. A display of 'pannicum seed, corn seed, pumpkins and melons' represented agricultural training. Formal schooling of children was reflected in the copybooks and drawing books. There were more than a dozen examples of garments, made by girls and women at the Home, ranging from utilitarian items such as a boy's flannel shirt to more decorative but still useful pieces including a 'muslin \& embroidery bonnet' and two muslin slip bodices 'trimmed with lace $\&$ embroidery'. Three chair cushions, a model hut and a model hay shed completed the display. ${ }^{29}$

The popularity of the first A boriginal court led to its inclusion in successive years. During the 1910s the court occupied an area of approximately 12 by 20 metres 'in one of the best positions in the main pavilion'. ${ }^{30}$ It consisted of up to 15 stalls and an area for special displays. A list of items for 1912 included:

Schoolwork - writing, drawing, printing etc.,

Sewing - samples, garments, table-linnen [sic],

Fancywork - knitting, beadwork, crochetwork,

Cooking - cakes, scones, bread etc.,

Carving - woodwork, implements, emu eggs,

Curios - weapons, model canoes and huts, ornaments, intensils [sic], implements, dancing masks,

Plaiting - cocoanuts [sic] and grass hats, bags, baskets, dresses, girdles etc. ${ }^{31}$

There were also photographs featuring activities at the reserves and missions. Each institution had its own section, staffed by officials and non-Indigenous 'friends'. A small number of Aboriginal people were also in attendance; the Indigenous women on duty at the stalls were clad in the uniform of domestic servants. Bleakley recalls that 'a number of uniformed native police were on duty to keep order. They created a favourable

28. Q ueenslander, 19 August 1911: 39.

30. Bleakley 1961: 190.

31. Letter from Deputy Chief Protector of Aboriginals to the Secretary, National Agricultural Association, 8 July 1912, QSA A/ 58677. 
impression with their courtesy and smartness. ${ }^{\prime 32}$ The special displays offered visitors an opportunity to observe Aboriginal people engaged in allegedly traditional activities against a backdrop intended to evoke a pre-colonial past, although the colonial reality was ever present and reflected, for example, in an identified need to ensure appropriate modesty of dress. Planning documents for the 1912 Exhibition referred to 'aboriginals who will provide in a true native gunyah, a separate show in themselves. They will comprise a fullblooded warrior in native costume (respectable) and his gin and piccaninny, also an old woman making baskets and an old man carving Emu Eggs.' 33

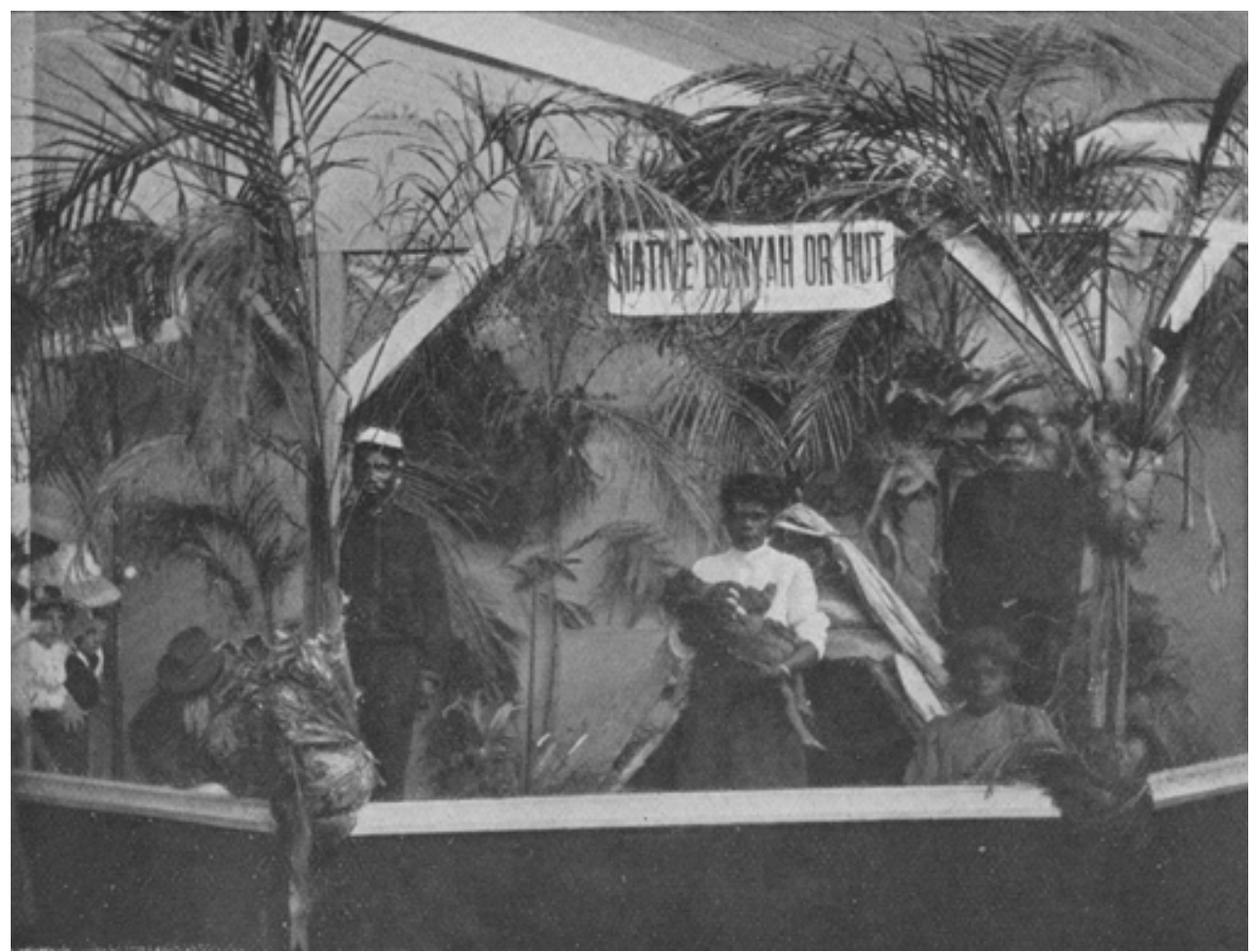

Fig 2. Native Camp - Aboriginal Section, Brisbane Exhibition, 1912, from the Annual Report of the Chief Protector of Aboriginals for the year 1912, Queensland Parliamentary Papers 3 , 1913.

The W eek referred to the 1912 court as 'the pre-eminent attraction in the annexes' and continued with high praise for the skills and craftsmanship visible in the various exhibits. ${ }^{34}$ As with the arrangement of the previous year, the 1912 displays offered a juxtaposition of the old and the new. Yarrabah Mission in northern Queensland, for example, featured three shelves and a long table of artefacts and items that showed an

32. Bleakley 1961: 190-191.

33. Letter from Deputy Chief Protector of A boriginals to the Secretary, $N$ ational A gricultural Association, 8July 1912, QSA A/ 58677.

34. Week, 23 A ugust 1912: 12. 
apparent evolution from the old ways to the new. The top shelf contained shields; the second boomerangs and small dilly bags; the third larger bags; and the table was occupied by modern clothing made by mission girls. ${ }^{35}$ At first glance this display seems counter-intuitive given that the 'primitive' items were arrayed on the top shelf while the newest and most 'civilised' items were placed on the lowest shelf. ${ }^{36}$ It seems likely that this presentation reflected the organisers' belief that the items which drew the eye of most visitors were the older, exotic items that hinted at more picturesque and violent times. Further, it seems reasonable to assume that, having gained the viewers' attention, the organisers hoped that the results of training and education would also be noticed and appreciated. Such an analysis, however, rests on limited evidence. No written rationales for the particular arrangements of items within the A boriginal stalls have been located. It is clear, though, that the Chief Protector of A boriginals Office regarded the annual exhibition as an opportunity to show off the achievements of the Queensland reserve and mission system. ${ }^{37}$

Three gunyahs formed the centrepiece of the 1912 court and other ostensibly authentic artefacts such as boomerangs, baskets and spears were also featured. This substantial foregrounding of the 'primitive' material culture again suggests the tactics of advertisement, with the use of exotic artefacts to attract initial attention. The crux of the displays, from the point of view of the organisers, consisted of objects which prefigured the results of reserve and mission-sponsored training. For male Aborigines, sisal rope making, matting and gardening were among the economically useful skills and items displayed. For girls and women, the domestic sciences, especially needlework, were emphasised. 'Mrs. Beeson, one of the government aboriginal protectresses, drew together from her protégés [sic] from all over the State specimens of needlework, and a careful examination of the work showed the wonderful skill and patience of the girls, who are all in domestic employ. ${ }^{38}$ As an employment broker through the system of Aboriginal employment permits and as the body that controlled the wages accrued under that system, the state had a vested interest in advertising the employability of Indigenous people.

The demonstrated impact of education and training was an important aspect of the Aboriginal court displays. Newspaper coverage drew attention to the successful education of Indigenous children with the Week referring to 'examples of schoolwork which compared more than favourably with the average capabilities of European children of similar age'. While this statement praised A boriginal students, most kudos was reserved for the white educators: 'the exhibit was a remarkably telling testimony to the efficacy of Queensland methods, both State and missionary, in connection with the treatment and training of the comparatively few remaining descendants of the original

35. A nnual Report of the Chief Protector of A boriginals for the year 1912, QPP 1913, 3: 11.

36. They may al so have been the oldest items, although no direct information on the age of the artefacts has been located.

37. Part of the impetus may have derived from occasional calls for the Commonweal th to assume responsibility for A borigines. See for example, A ustralian Association for the Advancement of Science, 'The Future of the Australian Aborigines', March 1913, a circular sent with a letter from the Chief Protector of A boriginals to the Under Secretary, H ome Department, $26 \mathrm{M}$ arch 1913, QSA A/ 58808, which is also relevant. 
possessors of the soil'. ${ }^{39}$ The $\mathrm{Q}$ ueenslander, which noted the encouraging work of mission and reserve training, nevertheless highlighted the distance between the races stating that 'the most interesting feature was undoubtedly the advance shown by the natives in the difficult process of emerging from their state of primitive barbarism into a condition approaching semi-civilisation' ${ }^{40}$ Based on newspaper reports, the A boriginal courts successfully focused attention on the outputs of the reserve and mission system; the conditions of daily life within the institutions were not acknowledged.

Doubtless the Chief Protector of A boriginals would have been gratified with this endorsement in the popular press of his department's educative efforts. The coverage reinforced his own message to parliament about government reserves and the training they offered, as demonstrated in the Exhibition displays:

Our own settlement at Barambah had some fine specimens of carved whip-handles and walking-sticks, home-made branding irons, wood-shaving dinner table mats, all of which showed evidence of patient and careful training on the part of the staff of the various institutions. ${ }^{41}$

The annual show had always promoted the economic utility of primary and secondary industries and the emphasis in the A boriginal displays on the utilitarian aspects of education and training conforms to this focus. For the official Protectors of A boriginal and Torres Strait Islander people, the Exhibition presented an ideal venue to display to the public the results of their efforts. The estimated attendance for show week in 1912, for example, was 163,000; Brisbane's population was then approximately 70,000 . By contrast the Queensland M useum attracted a maximum of 75,000 visitors per year. ${ }^{42}$ Additionally, the show provided an opportunity for the reserve and mission staff to demonstrate their achievements to the Chief Protector's Office and, in turn, for the Chief Protector's Office to demonstrate its achievements to its political masters.

The motif of the triumph of civilisation over primitivism was an important part of the Aboriginal courts and the purpose-built gunyahs, together with boomerangs, spears and other weapons arrayed alongside schoolwork and needlework, allowed the public to compare the old and the new, the archaic and the modern. Significantly, this artefact driven display of the 'evolution' of Aboriginal peoplefrom primitives to useful and productive workers signalled a departure from the Social Darwinist ideology of inevitable demise. This change in thinking was also visible in the annual reports of the Chief Protector of A boriginals from this period, with the A boriginal courts providing government officials with a medium through which they could communicate their new theory. ${ }^{43}$ Despite this change in thinking in some quarters, however, in general the Queensland public, its parliamentarians and its media remained wedded to their belief in the 'dying race' theory. The W eek proclaimed in 1916 that 'One al ways looks upon the schoolwork

39. W eek, 22 A ugust 1913: 10.

40. Q ueenslander, 23 August 1913: 39.

41. A nnual Report of the Chief Protector of A boriginals for the year 1913, QPP 1914, 3: 4.

42. Q ueenslander, 24 August 1912: 20; Mather 1986: 105. Of course, the attendance figures do not reveal how many individuals visited the A boriginal courts at the Exhibition or the A boriginal displays at the Museum.

43. As early as 1910, the Chief Protector commented that, 'it is at least possible those persons are mistaken who regard the extinction of aborigines as a painful certainty'. A nnual Report of the Chief Protector of A boriginals for the year 1910, QPP 1911-12, 3: 10. 
and handiwork of our black population with a sense of respect for the intelligence that is so tardily being developed now that the race is passing away'. ${ }^{44}$ As occurred at other types of exhibitions, the intended message was not always embraced by the audience. Ewan Johnston comments in his study of the presentation of Fiji at international and intercolonial expositions that, 'despite the best efforts of display organisers, ... visitors as al ways - saw what they wanted to'. ${ }^{45}$

The state sought a careful balance between segregation and assimilation: whilethe reserves and missions operated to separate white and black society, the settlers could be reassured that Indigenous Queenslanders were sufficiently integrated into the values of white society to support patriotic endeavours. After the 1915 Exhibition, the Chief Protector wrote that 'it is pleasing to record that some fine models of native outrigger canoes were afterwards sold by auction, at the request of the makers, for the benefit of the Bel gian Fund'. ${ }^{46}$ The following year, in the wake of the first anniversary of the Gallipoli landings, the patriotic nature of the A boriginal displays at the Brisbane Exhibition mirrored that of the broader society, with the Chief Protector noting in particular in that year's court, 'a very fine recruiting poster in the shape of a crayon map of the Dardanelles, decorated with patriotic emblems and portraits of the leading generals' ${ }^{47}$

Despite the avowedly high-minded motivation of the Aboriginal courts, a voyeuristic outlook, usually associated with the 'delights' of sideshow alley, informed the relationship between audience and displays. Bleakley noted that the 1912 display, which featured an A boriginal mother and child sitting in front of a gunyah, prompted a great response from visitors: 'So many pennies and small coins were showered upon it that a box had to be provided, and it will be interesting to hear that the little mite left the show with over $£ 12$ in the bank, richer than its [sic] parents have ever been. ${ }^{48}$ The presentation of live 'exhibits' directly contrasted with the more prosaic Aboriginal campsite diorama that opened at the Queensland Museum in 1914 and featured models of an Indigenous family.

The display of A boriginal people at the Exhibition offered a peculiar combination of elements of traditional life - a gunyah - with a sanitised version of life on reserves and missions, represented by the mother's clothing. She was very modestly dressed, clad in a full-length skirt, long-sleeved blouse, stockings and closed-in shoes. The display was repeated in the following year and again received strong interest, with the Q ueenslander noting that it:

attracted a large number of visitors throughout the week and many of them showed their appreciation by presenting small coins to the black gin and pickaninny who established their quarters in the native gunyah at the back of the court. Altogether a sum of nearly $£ 10$ in coppers was handed to the ebon-faced, ever smiling pickaninny, who had become quite a favourite with visitors. ${ }^{49}$

\footnotetext{
44. Week, 18 A ugust 1916: 16.

45. Johnston 2005: 24.

46. A nnual Report of the Chief Protector of A boriginals for the year 1915, QPP 1916, 3: 3.

47. A nnual Report of the Chief Protector of A boriginals for the year 1916, QPP 1917, 3: 3. The report al so notes instances where prizes were donated to patriotic funds and that Mission children made bandages for the war effort.

48. A nnual Report of the Chief Protector of A boriginals for the year 1913, QPP 1914, 3: 4.

49. Queenslander, 23 August 1913: 39.
} 
Exactly why this display provoked such a strong response is difficult to ascertain. Certainly by the 1910s A boriginal people were infrequently encountered by the citizens of Brisbane and may have been viewed as somewhat exotic. Bleakley's recollections confirm this possibility: 'This exhibit itself attracted crowds of curious sightseers, to many of whom the bonny velvet-skinned baby was a real novelty. ${ }^{50}$ That 'novelty' may explain the spontaneous donations of coins, with visitors to the annual show accustomed to paying sideshow proprietors, to see oddities including 'freaks' of nature and talents such as snake charming. The appeal of a reworking of the classical image of mother and child may also have influenced the crowds.

The Aboriginal courts were an annual feature from 1911 until 1917 when they were discontinued, officially 'because of the need for stringent war-time economies', although the timing is coincident with the state Labor government's determination to minimise 'race mixing' by reducing A boriginal employment outside the reserves and missions. ${ }^{51}$ Bleakley expressed regret at the cancellation of the courts, but later declared that they had achieved their aims. In his 1961 volume, he stated: 'To their inestimable value as a means of enlightening the public on the capacity of the aboriginal race for upliftment and education, can be attributed the greater understanding and sympathy that, from then on, ensured the much needed practical encouragement in the work for their preservation. ${ }^{52}$ The A boriginal presence at the Exhibition during this period acted principally as an advertisement for the missions and reserves. The juxtaposition in the presentation of the old - gunyahs, spears and boomerangs - with the new schoolwork, needlework and small-scale manufacturing and farming, let the public gain an insight into the vision for Indigenous Queenslanders promoted by Bleakley and his supporters: namely, that they could be trained to be useful to the broader society and economy of the post-frontier era. Ironically, it was probably the 'exotic' - the displays of weapons and traditional artefacts as well as the living exhibits - that most appealed to the sightseers, rather than the sewing samplers, copybooks and other items that the organisers hoped would leave the greatest impression. Certainly, the reported response to the A boriginal mother and child seems to confirm this suspicion.

Even with the inclusion of live exhibits, the Aboriginal courts were notable for being relatively static and passive. The two examples of items being created as the audience watched - basketmaking and emu egg carving - did not require the creators to move around the site. From as early as 1876, the Exhibition always featured a combination of moving and static displays. Many of the active elements of the 19th and early 20th century shows, such as woodchopping and horse riding competitions, were closely connected to the successful colonisation and exploitation of the land. The contained and controlled nature of the Aboriginal exhibits of the 1910s, including the people displayed, reflected the official protectors' view of Indigenous people as a nonthreatening source of domestic and rural labour.

The state organisation of these displays distinguishes them from what Michael Parsons has identified as public, cultural performances by A boriginal people that constituted 'a significant and successful attempt to use symbolic goods to engage in the

50. Bleakley 1961: 191.

51. Bleakley 1961: 191.

52. Bleakley 1961: 191. 
settler economy'. ${ }^{53}$ While an A boriginal theatrical company, which performed in the Brisbane suburb of Coorparoo in 1896 and may have been organised by Indigenous people, does fit with and is included in Parson's analysis, the formal inclusion of Indigenous people at the Exhibition in the 1910s does not. The sale of goods at the Exhibition produced by Indigenous Queenslanders represented engagement in the settler economy but that engagement was directed by and ultimately for the benefit of the state apparatus that controlled and exploited Aboriginal people.

The courts promoted the role of government and churches in the management and education of Aboriginal people. A part from the appearance in sideshow alley of the tent boxing shows, with their A boriginal fighters, the role of the private sector in matters pertaining to A boriginal people was only indirectly on display at the Brisbane Exhibition. While the labour of A boriginal employees on pastoral properties and farms contributed significantly to the production of some of the livestock and agricultural outputs at the annual show and while the work of some A boriginal domestic servants undoubtedly freed up the time of their white mistresses, allowing them to create entries for the Exhibition, that labour was not usually visible at the show itself. ${ }^{54}$ The single exception to this pattern in the period under examination occurred in 1916 when a farmer based outside Townsville in northern Queensland, Joseph Campbell, presented his 'A boriginal curio and economic exhibit' in the Textile Fibres court of the Exhibition. While the primary purpose of the display was to alert Queenslanders to the potential of locally grown 'textile plants' that could be converted into fibre and paper, a photograph of the display reveals a bizarre array of human skulls, other bones, Aboriginal weapons, baskets, cloth, paper and rope, with two signs drawing attention to 'fibres, oils, gums, varnishes and foodstuffs'. Elements of the display thus shared common features with the ethnographic displays of the 19th century and the sideshows of the early 20th century. Many, perhaps all, of the manufactured items, had been made by Aboriginal workers, and the inspiration for the use of the textile plants came from one of Campbell's A boriginal servants. According to Campbell:

While working at the pineapple, my aboriginal servant Sam said: 'Boss, that one wild pineapple, that grow along swamp where cut firewood all same as this. He make him paper too.' 'Well done, Sam,' said I, 'go and get some at once.' He did so, and in six hours it was converted into the sample of paper exhibited. ${ }^{55}$

The report of this episode notes that Sam received two shillings for his discovery and while this does mark some engagement with the settler economy it says more about the exploitation of Indigenous knowledge for profit than it does about individual agency. With the exception of this single exhibit, the representation of Indigenous people in the formal displays at the Brisbane show in the 1910s was controlled by the state which offered a version of race relations in which Indigenous people could be useful

53. Parsons 1997: 48.

54. The relative lack of attention paid to the labour that contributed to the exhibits was not restricted to Indigenous workers; with some exceptions, such as prizes for craftsmanship, the Brisbane Exhibition focused on outputs and the technology that facilitated those outputs, rather than the workers involved in the processes. Queensland A gricultural Journal, October 1916: 237. 
and pliant adjuncts to the enterprise of white progress and civilisation, while affording entertainment for the crowds who attended the Exhibition each year.

Surviving records about the Aboriginal courts enable a textual analysis of the intentions of government and mission officials and provide some insight into the responses of the white audiences who flocked to the exhibits, purchased mementos and tossed coins to the live exhibits. The Indigenous creators of the items on display, however, are represented only through the items themselves and their names in the prizewinners' lists, published in the local newspapers. ${ }^{56}$ The thoughts of the family group displayed for the edification and entertainment of the crowds are unknown. A vailable accounts do not enable us to determine whether individual Aboriginal exhibitors derived pleasure, satisfaction or even pride in the display of their products. We do not know whether the individuals 'on display' enjoyed or detested the experience, regarded the sightseers with contempt or curiosity, welcomed or shunned the chance to leave their institution during Exhibition week. This inconclusive analysis directly contrasts with Jane Lydon's confident argument in her study of Coranderrk's A boriginal people in Victoria: 'by the end of the 19th century there was a ready acceptance by black and white of the deployment of stereotypical, artificial representations of Aboriginal people as a means of cultural communication within the colonial relationship'. ${ }^{57}$ There is insufficient evidence in relation to the Brisbane Exhibition to offer such a definitive conclusion. The reactions of A boriginal visitors to the show remain almost entirely in the real $m$ of speculation. Whereas some cautious conclusions can be reached about the responses of white visitors, no references to Aboriginal people as part of the Exhibition audience in this era have been located, beyond the indications that reserves and missions arranged 'outings' to the annual agricultural show.

Given the scope of control exercised by the missions and reserves over their charges under Queensland regulations, it seems unlikely that the A boriginal participants had much, if any, control over the content or style of the displays, beyond their power to determinethe quality of individual items. Even this element of autonomy was constrained by the issue of access to materials. The correspondence between the Deputy Chief Protector and the mission and reserve superintendents indicates that the planning, content and structure of the displays were the domain of officials. This deployment of power does not eliminate the possibility of pride amongst the creators of the displayed items. Yet any positive impact on those individuals that did occur was an accidental by-product of the state's plan to train Indigenous Queenslanders to be economically useful and pliant, and the eagerness of officials to publicise the achievements of their institutions.

\section{Condusion}

The Aboriginal presence at the Exhibition did not end with the cancellation of the courts after 1917. The tent boxing shows in sideshow alley marked an ongoing Indige-

56. A part from a few exceptions where the reserves and missions failed to provide the names of the residents who created the items, the newspapers listed A boriginal prizewinners by either their full names or their first names. The lists were organised by reserve and mission name, followed by prize category and then creators' names, giving primacy to the institution, rather than the individual. See for exampleW eek, 22 August 1913: 10.

57. Lydon 2005: 203-04. 
nous role at the annual agricultural show, and in later decades, the Chief Protector's Office renewed its engagement with the Exhibition as a site at which it could promote itself and its values. The 1910s, however, marked the heyday of an A boriginal presence in the formal, regulated and respectable section of the most significant annual event in Brisbane. The extent and popularity of the courts in this decade offer a dramatic contrast to the near absence of Indigenous people, as represented through items by or about them, during the early years of the show. That absence derived from an amal gam of features ranging from the aims of and intended audience for the Exhibition to the ongoing conflict between colonists and Indigenous people in the far reaches of Queensland, and existed in counterpoint to the simultaneous incorporation of Indigenous people and artefacts into international expositions and circuses.

In an era of segregation, the A boriginal courts of the 1910s constituted the pre eminent, if fleeting, encounter with A boriginal culture for most members of the general public. Under Bleakley's direction, government and church officials sought to present a sanitised view of Aboriginal life on reserves and missions, and began the process of converting the widespread belief in Queensland in the 'dying race' ideology to a commitment to a permanent but segregated Indigenous presence. Examples of agricultural outputs from the institutions, schoolwork, carefully worked garments, and photographs emphasised the self-proclaimed achievements of the reserves and missions, particularly in relation to the production of a compliant and useful workforce through training. For the white sightseers who made the Aboriginal courts one of the most popular elements of the Exhibition, however, it was the presence of living exhibits and perhaps the exotic items, such as traditional weapons, that aroused excitement. The transmission of the Chief Protectors Office's intended message to the public was not always successful. Within the unequal power relations that characterised white-black interaction in Queensland and were replicated at Brisbane's annual agricultural show, the difficulty of offering any conclusive description, let al one analysis, of the reactions of those Indigenous Queenslanders who participated directly or indirectly in the Exhibition, itself provides a stark example of the power of colonialism.

\section{References}

\section{Primary sources}

Australian Association for the Advancement of Science, 'The Future of the Australian A borigines', March 1913.

Deebing Creek A boriginal H ome List of Exhibits, July 1911, Queensland State Archives (QSA) A/ 58808.

Letter from the Chief Protector of A boriginals to the Under Secretary, Home Department, 26 March 1913, QSA A/ 58808.

Letter from Deputy Chief Protector of A boriginals to the Secretary, N ational Agricultural Association, 8July 1912, QSA A/ 58677.

Memorandum from Deputy Chief Protector of A boriginals, 1July 1911, QSA A/ 58808.

Queensland Intercolonial Exhibition 1876 Catalogue. 


\section{Newspapers}

Q ueensland A gricultural Journal

Q ueenslander

W eek

\section{Secondary sources}

Anderson, Kay 2003, 'White natures: Sydney's Royal A gricultural Show in posthumanist perspective', Transactions of the Institute of British G eographers 28: 422-441.

A nnual Report of the Chief Protector of A boriginals for the year [1909, 1910, 1912, 1913, 1915, 1916], Queensland Parliamentary Papers (QPP).

Bank, Rosemarie 2002, 'Representing history: performing the Columbian Exposition', Theatre Journal 54(4): 589-606.

Blake, Thom 1987, 'Excluded, exploited, exhibited: A borigines in Brisbane 1897-1910' in Brisbane: A boriginal, alien, ethnic, Brisbane History Group Papers 5: 48-58.

Bleakley, JW 1961, The A borigines of A ustralia, Jacaranda Press, Brisbane.

Broome, Richard 1996, 'Theatres of power: tent boxing circa 1910-1970', A boriginal History 20: 1-23.

Broome, Richard with Alick Jackomos 1998, Sideshow A lley, Allen \& Unwin, St Leonards.

Department of the Public Instruction 1913, Q ueensland School Readers, Book V, Department of the Public Instruction, Brisbane.

Edmonds, Penelope 2006, 'The Le Souef Box: reflections on imperial nostalgia, material culture and exhibitionary practice in colonial Victoria', A ustralian H istorical Studies 127: 117-39.

Evans, Raymond 2001, 'Brisbane at Federation: 1899-1902', in 0 ur Federation: Brisbane: patriotism, passion and protest 1901, Barry Shaw (ed), Brisbane History Group Papers 18: 69-79.

Evans, Raymond, Kay Saunders and Kathryn Cronin 1993, Race relations in colonial Queensland: a history of exclusion, exploitation and extermination, 3rd edn, University of Queensland Press, St Lucia.

Greenhalgh, Paul 1988, Ephemeral vistas: the expositions universelles, great exhibitions and world fairs, 1851-1939, Manchester University Press, Manchester.

Heaman, EA 1999, The inglorious arts of peace: exhibitions in Canadian society during the 19th century, University of Toronto Press, Toronto.

Johnston, Ewan 2005, 'Re-inventing Fiji at 19th-century and early 20th-century exhibitions', The Journal of Pacific H istory 40(1): 23-44.

Logan, Greg 1989, 'Irish, royal and red: Thestory of Queensland's School Readers', Educational Historian 2(3): 1-7.

Lydon, Jane 2005, Eye contact: photographing Indigenous A ustralians, Duke University Press, Durham.

Mather, Patricia 1986, A time for a museum: the history of the Q ueensland M useum 1862-1986, Queensland Museum, South Brisbane.

McKay, Judith 1998, 'A good show: colonial Queensland at international exhibitions', M emoirs of the Queensland M useum: Cultural Heritage Series 1(2): 175-343. 
— 2004, Showing off: Q ueensland at world expositions 1862-1988, Central Queensland University Press, Rockhampton.

Parsons, Michael 1997, 'The tourist corroboree in South A ustralia to 1911', A boriginal H istory 21: 46-69.

Poignant, Roslyn 2004, Professional savages: captive lives and western spectacle, Yale University Press, New Haven.

Rutlidge, Charles 1897, Guide to Q ueensland and the International Exhibition, 1897, Australian Publishing and Advertising, Brisbane.

Rydell, Robert 1984, A Il the world's a fair, University of Chicago Press, Chicago.

— 1993, W orld of fairs, University of Chicago Press, Chicago. 